\title{
The development of teaching materials based on problem solving exploration with microsoft kaizala applications
}

\author{
Nenden Mutiara Sari ${ }^{1}$, Ana Setiani ${ }^{2}$, Ina Rinangkit ${ }^{3}$, Hanhan Subhan \\ Munawar4 \\ ${ }^{1}$ Universitas Pasundan, Indonesia \\ ${ }^{2}$ Universitas Muhammadiyah Sukabumi, Indonesia \\ ${ }^{3}$ SMPN 50 Satap Oku, Indonesia \\ ${ }^{4}$ SMAN 1 Cikalongwetan, Indonesia \\ $\triangle$ nenden.mutiara@unpas.ac.id *
}

\section{Article Information \\ Submitted June 21, 2021 \\ Revised July 06, 2021 \\ Accepted July 14, 2021}

\section{Keywords}

Exploration;

Microsoft Kaizala;

Problem Solving;

Teaching Material

\begin{abstract}
The effectiveness of implementing online learning during the COVID-19 pandemic has not been satisfactory in terms of problem-solving abilities. The presentation of teaching materials presented in the online platforms used has not been able to identify the extent of student understanding in problem-solving exploration. Therefore, this research aims to produce Kaizala teaching materials based on problem-solving exploration. The ADDIE (Analysis, Design, Development, Implementation, Evaluation) development model was used in this research to produce these teaching materials. The subjects of this research trial were grade VIII junior high school students in a public school in Ogan Komering Ulu Regency, Palembang. The choice of the place for this research was based on the fact that the mathematics learning carried out at the school was by utilizing social media platforms. The instruments used in this research consisted of validation sheets of material, language, presentation, and problem-solving integration, a questionnaire on the practicality of teaching materials, and a problem-solving ability test to assess the effectiveness of the developed teaching materials. The results showed that: (1) the developed teaching materials were in the valid criteria; (2) the practicality of the developed teaching materials are at very high and high criteria; (3) The developed teaching materials also meet the criteria of effectiveness, whereas many as 82 percent of the test subjects obtained a score of not less than 75 and the effect size value belongs to the large category. Thus, it can be concluded that the developed teaching materials are suitable for supporting and facilitating students in problem-solving exploration activities.
\end{abstract}

\section{INTRODUCTION}

As a critical competency of the 21st century, problem solving has received widespread attention in worldwide education systems and has become one of the main targets of education in PISA (Pellegrino, 2017). In school, mathematics is the core subject that is most closely related to problem-solving. Therefore, a fundamental goal of learning mathematics in schools is to develop students' ability to solve complex problems (Felmer et al., 2019; Jäder et al., 2020). So far, many methods, models, and approaches have been used to improve students' mathematical problem-solving abilities. However, some research results show that junior high school students' mathematical problem-solving ability is still relatively low (Abdiyani et al., 2019; Rianti, 2018).

With the COVID-19 pandemic, learning activities that had to be carried out face-to-face are now being carried out online (Kemdikbud, 2020). The goal is to break the chain of the 
spread of COVID-19. Various polemics occurred at the beginning of this online learning policy, such as: parents have to accompany their children to study (Abuhammad, 2020; Anugrahana, 2020), teachers' low mastery of technology, limited facilities owned by students, and poor internet connection (Asmuni, 2020; Octaberlina \& Muslimin, 2020), plagiarism in carrying out tasks such as copying answers from friends and the internet (Saefulmilah \& Saway, 2020), the delivery of learning materials by teachers is not creative and innovative (Huzaimah \& Amelia, 2021). Most elderly teachers find it challenging to carry out online learning because they are not used to using technology and the internet. (Saepudin, 2019) stated that the longer the teacher teaches, the lower the level of ICT literacy. Even so, the compulsion factor makes teachers have no other choices but to start learning to use technology and the internet.

Although several months have passed after the online learning policy, teachers have become accustomed to using technology, but student learning outcomes are unsatisfactory. This fact is supported by the results of a questionnaire given to teachers, showing that curriculum targets' level of curriculum targets during online mathematics learning is only 24.3\%. The study results even showed that during the COVID-19 pandemic, the effectiveness of the implementation of online learning was not satisfactory enough in terms of problemsolving abilities (Saragih \& Ansi, 2020).

Based on the results of surveys and research, the learning media that are widely used so far are WhatsApp, google classroom, email, zoom, and Moodle (Gunawan et al., 2020; Septiani \& Setyowati, 2020). The practice of learning mathematics using these applications is usually carried out in stages: (1) distributing learning materials in the form of pdf, PowerPoint, or Word files on the applications used; (2) giving orders to read/understand the material given; (3) asking students to complete the questions given in the material; and (4) collecting assignments that have been given. The material provided is usually in the form of teaching materials or modules designed by the teacher and stored in the file format mentioned above. Although teachers design the teaching materials provided to achieve specific competencies, it is difficult for teachers to monitor how students understand the material provided. This monitoring aims to diagnose student learning difficulties so that teachers can improve students' ability to solve problems.

Therefore, it is necessary to think about designing teaching materials that can improve students' mathematical problem-solving abilities. (Sari et al., 2019) stated that the difference in the presentation of teaching materials impacted in improving students' problem-solving abilities. In addition, the research results of (Pogaga, 2020) show that the application of a variety of methods, media, and teaching materials, as well as interactions in learning, can stimulate student involvement in the process of expressing opinions, enthusiasm, initiative, questions, and assignments in online learning activities. This teaching material must also be able to identify where students have difficulty during the problem-solving process.

The Microsoft Kaizala application was created to resemble the WhatsApp application that already existed. Microsoft Kaizala first appeared in 2017 at garage India. (Microsoft, 2020) claims that this application has features that can make it easier for workers to complete their work. Apart from work, Ms. Kaizala can also be used for learning purposes like Whatsapp. The following shows some of the features of the Microsoft Kaizala that can be used during online learning. 


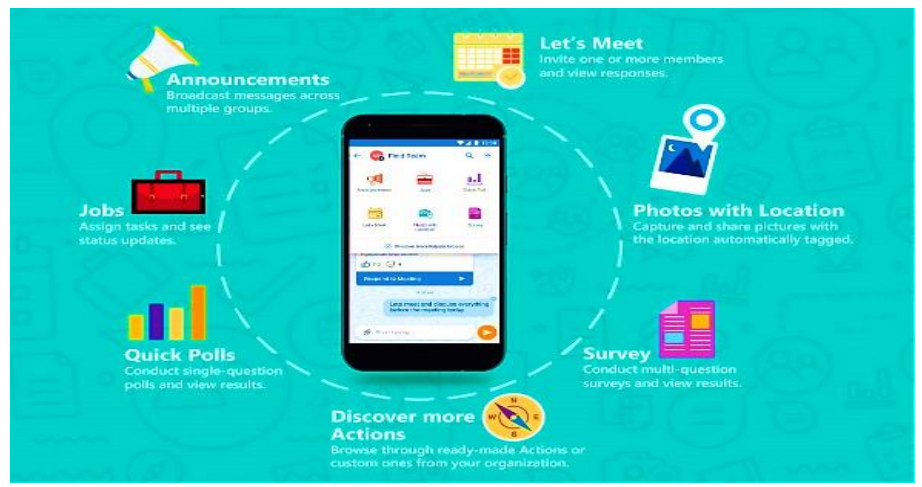

Figure 1. Microsoft Kaizala action features

Some research results show that the exploratory approach can support students' problem-solving abilities (Barham, 2019; Sari, 2015; Susilawati et al., 2017) because the syntax in the exploratory approach is similar to the problem-solving syntax of (Polya, 2004). So far, there have been two relevant researches related to the development of teaching materials using the Microsoft Kaizala application, including improving creative thinking skills (Susilawati, 2020) and improving critical thinking skills (Ansori, 2019). However, in these two researches, the preparation of teaching materials has not utilized the action survey feature, which is advantageous. The difference between this research and previous research lies in the difference in teaching materials that using action surveys. The development of teaching materials through this feature can train students to find concepts through problemsolving exploration step by step. (Gracin, 2018) stated that the compiled mathematics textbooks should facilitate students in finding mathematical concepts. In addition, through this application, teachers can monitor students' difficulties during the learning process. Thus, this can help the teacher to focus on the parts that students do not understand. Therefore, this research aims to develop a Kaizala teaching material based on problem-solving exploration.

\section{METHODS}

This research is a research and development $(\mathrm{R} \& \mathrm{D})$ that aims to produce a suitable product for use in terms of validity, practicality, and effectiveness. The resulting product is a teaching material based on problem-solving exploration integrated into the Microsoft Kaizala on the Pythagorean matter. This research was conducted using the ADDIE development model. This development model consists of five development stages: analysis, design, development, implementation, and evaluation (Muruganantham, 2015). This model procedure is given below:

ADDIE Model

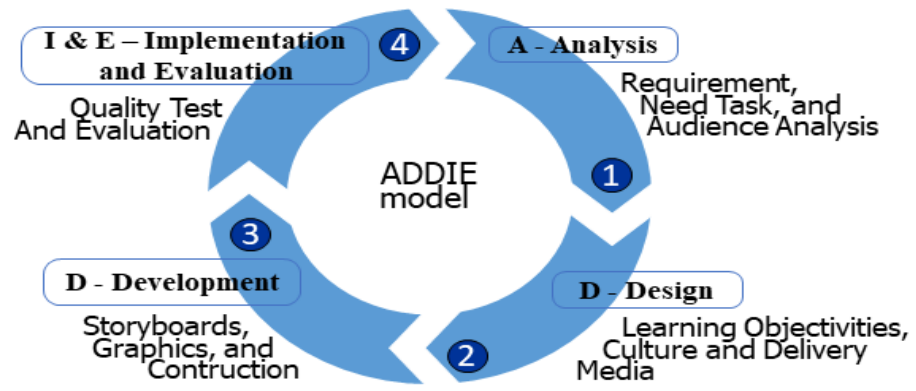

Figure 2. ADDIE Model 
The subjects in this research were 17 students of 8th grade of SMP Negeri 50 Satap Oku, Komering Ulu Regency, South Sumatra, two lecturers of mathematics education, two mathematics teachers, and one media expert. The instruments used in this study consisted of: (1) material validation sheets, language, presentation, and problem-solving integration; (2) a questionnaire on the practicality of teaching materials (3) a guide to student readability tests; and (3) a problem-solving ability test to assess the effectiveness of the teaching materials developed.

Each validation sheet has five categories of assessment, namely very good, getting a score of 5; good, getting a score of 4; just good, getting a score of 3; less good, getting a score of 2; and very less good, getting a score of 1 . In the practicality questionnaire of teaching materials, students are given two answer choices. i.e., Yes or No. Scoring of each question uses the Guttman scale as follows:

Table 1. Guttman Scale

\begin{tabular}{ll}
\hline Answer & Score \\
\hline Yes & 1 \\
\hline No & 0 \\
\hline
\end{tabular}

This research used two types of data analysis techniques, namely qualitative and quantitative descriptive data analysis techniques. Qualitative data analysis techniques were used to analyze the data from the expert reviews and the results of the readability test by students. The quantitative descriptive data analysis techniques were used to process and analyze the data from expert validation, student response questionnaires using Kaizala teaching materials, and problem-solving ability test results. The data analysis results were then used to determine the validity, practicality, and effectiveness of the developed Kaizala teaching materials. According to Nieveen et al. (1999), to produce good quality learning tools, these learning tools must have validity, practicality, and effectiveness.

The instrument used in this research was a questionnaire validation of teaching materials. This questionnaire is used to measure the level of validity of teaching materials based on expert judgment. The experts in question consist of two mathematics teachers, two mathematics education lecturers, and one expert media. The validity test is seen from 4 aspects: content feasibility, presentation feasibility, language feasibility, and problem-solving integration. The formula used to calculate the validity value is as follows:

Validity value $(\mathrm{Val})=\frac{\text { the total value of each statement }}{\text { maximum value }} \times 100 \%$. The combined value to calculate the validity of several statements, the following formula is used.

$$
\mathrm{v}=\frac{\mathrm{Val}_{1}+\mathrm{Val}_{2}+\cdots+\mathrm{Val}_{\mathrm{n}}}{\mathrm{n}}
$$

The developed Kaizala teaching materials are said to meet the validity criteria if the average of validity score obtained is fairly valid. Therefore, the analysis of the validity level of the Kaizala teaching materials in this research used the validity criteria as shown in the following table:

Table 2. Validity Level Category

\begin{tabular}{ccl}
\hline No. & Percentage Value $(\mathrm{p})$ & Category validity level \\
\hline 1 & $85 \%<p \leq 100 \%$ & Very valid, or used without revision \\
\hline 2 & $70 \%<p \leq 85 \%$ & Fairly valid or usable but need minor revision \\
\hline 3 & $50 \%<p \leq 70 \%$ & Less valid, it is recommended not to use it because it needs a major revision \\
\hline 4 & $0 \% \leq p \leq 50 \%$ & Invalid, should not be used \\
\hline
\end{tabular}


The formula used to calculate the practicality percentage of teaching materials is practicality $(\%)=\frac{\text { total score for each statement }}{\text { number of respondents }} \times 100 \%$. The interpretation of practicality scores based on student responses can be seen in the following table 3 .

Table 3. The Practicality Categories of Teaching Materials

\begin{tabular}{ll}
\hline Percentage $(\mathrm{p})$ & Category \\
\hline $0 \% \leq p \leq 20 \%$ & Not practical \\
\hline $20 \%<p \leq 40 \%$ & Less practical \\
\hline $40 \%<p \leq 60 \%$ & Practical enough \\
\hline $60 \%<p \leq 80 \%$ & Practical \\
\hline $80 \%<p \leq 100 \%$ & Very practical \\
\hline
\end{tabular}

To measure the effectiveness of Kaizala teaching materials on students' problem-solving abilities, the effect size formula for paired samples is as follows:

$$
\text { Cohen's } d=\frac{\bar{d}}{s_{d}}
$$

Where, $\bar{d}=$ the average value of the difference and $S_{d}=$ the value of the standard deviation of the difference. The calculation results of effect size are interpreted using the classification according to Cohen (Becker, 2000), namely:

Tabel 4. Klasifikasi Effect Size

\begin{tabular}{cl}
\hline Effect Size & Cohen's Standard \\
\hline $0.8 \leq d \leq 2.0$ & Large \\
\hline $0.5 \leq d<0.8$ & Medium \\
\hline $0.2 \leq d<0.5$ & Small \\
\hline
\end{tabular}

The stages of developed Kaizala teaching materials using the ADDIE model are described further in the following table:

Table 5. The Stages of Developed Kaizala Teaching Materials

Based on Problem Solving Exploration

\begin{tabular}{lll}
\hline $\begin{array}{l}\text { Development } \\
\text { Stage }\end{array}$ & Activities & Expected output \\
\hline Analysis & Needs analysis & $\begin{array}{l}\text { Identified problems that exist in the learning } \\
\text { process and the condition of class VIII } \\
\text { mathematics teaching materials at SMPN 50 } \\
\text { Satap Oku }\end{array}$ \\
\hline Curriculum Analysis & $\begin{array}{l}\text { The material that will be composed of teaching } \\
\text { materials consists of sub-chapters material, } \\
\text { namely: Pythagorean Theorem, Pythagorean } \\
\text { Triples, and particular angles }\end{array}$ \\
\hline Design & $\begin{array}{l}\text { Analysis of student } \\
\text { characteristics }\end{array}$ & $\begin{array}{l}\text { Identified student characteristics during online } \\
\text { math learning activities }\end{array}$ \\
\hline $\begin{array}{l}\text { Develop Kaizala } \\
\text { teaching materials and } \\
\text { their } \\
\text { instruments evaluation }\end{array}$ & $\begin{array}{l}\text { Kaizala teaching materials are made, which are } \\
\text { arranged in the exploration stage of problem- } \\
\text { solving in the form of the prototype I, which is } \\
\text { ready to be validated by the validator }\end{array}$ \\
\hline $\begin{array}{l}\text { Assessment of the } \\
\text { Kaizala } \\
\text { materials teaching } \\
\text { namely prototype I, by } \\
\text { the validator }\end{array}$ & $\begin{array}{l}\text { Obtained comments and suggestions from } \\
\text { experts (validators) related to exploration-based } \\
\text { Kaizala teaching materials, namely prototype I, } \\
\text { which was produced }\end{array}$ \\
\hline $\begin{array}{l}\text { Revise/ improve the } \\
\text { Retrieved Kaizala teaching materials that have }\end{array}$
\end{tabular}




\begin{tabular}{lll}
\hline $\begin{array}{l}\text { Development } \\
\text { Stage }\end{array}$ & Activities & Expected output \\
\hline $\begin{array}{l}\text { developed Kaizala } \\
\text { teaching materials }\end{array}$ & $\begin{array}{l}\text { been revised according to the expert inputs } \\
\text { (validators). The revised teaching materials are } \\
\text { in the future referred to as prototype II }\end{array}$ \\
\hline Implementation & $\begin{array}{l}\text { Conducted a limited } \\
\text { trial at SMPN 50 Satap } \\
\text { Oku Palembang }\end{array}$ & $\begin{array}{l}\text { Obtained data on the practicality and } \\
\text { effectiveness of the developed Kaizala teaching } \\
\text { materials (prototype II) }\end{array}$ \\
\hline Evaluation & $\begin{array}{l}\text { Make revisions based } \\
\text { on the results of limited } \\
\text { trials that have been } \\
\text { carried out in schools }\end{array}$ & $\begin{array}{l}\text { The production of Kaizala teaching materials } \\
\text { that are suitable for use in learning (final }\end{array}$ \\
\hline
\end{tabular}

\section{RESULTS AND DISCUSSION}

At the analysis stage, it was identified that grade VIII students at SMPN 50 Satap Oku were less involved in online learning activities. The results of this analysis are same as the research conducted by (Aminullah et al., 2021), which states that student involvement in online learning is still not optimal. The reason is that the teaching materials provided during the learning process are only in soft files and assignments. Several researches that discussed online learning during the COVID-19 period showed that online learning encourages students to be passive. They only read every teacher's instructions and carry out their instructions without being fully and actively involved in learning activities (Argaheni, 2020).

On the other hand, student engagement is positively correlated with student achievement (Dharmayana et al., 2012; Reyes et al., 2012). Lack of student engagement in learning is a barrier to the student math concepts mastery. The concepts mastery is the basis of knowledge that students must possess to become good problem solvers. The research results of (Jusnita, 2018; Silaban, 2014) show a positive correlation between conceptual understanding and students' problem-solving abilities.

Mathematical problem solving is a common goal in mathematics learning and is even at the heart of mathematics (Branca, 1980; Son \& Lee, 2020). This ability must, certainly, get special priority so that learning objectives can be achieved. (Saragih \& Habeahan, 2017) said that problem solving is a part of learning mathematics because the process and completion must use the abilities and experiences they have previously. However, during the online learning process, teachers rarely practice students' problem-solving abilities. The research results of (Apriadi et al., 2021; Kurniawan et al., 2020; Zakiyah et al., 2021) show that during online learning, students' mathematical problem-solving abilities are included in the low category.

At the design stage, the research team compiled teaching materials on the Pythagorean material. The teaching materials are organized into three sub-chapters: (1) Pythagorean theorem, Pythagorean triples, and right triangles and particular angles. Each sub-chapter is arranged based on the exploration learning stages in the form of a draft. Then the teaching materials are made in the Microsoft Kaizala application using an action survey. At this stage, the produced teaching materials are prototype I. An example of the design of Kaizala teaching materials based on problem-solving exploration can be seen in the figure below: 


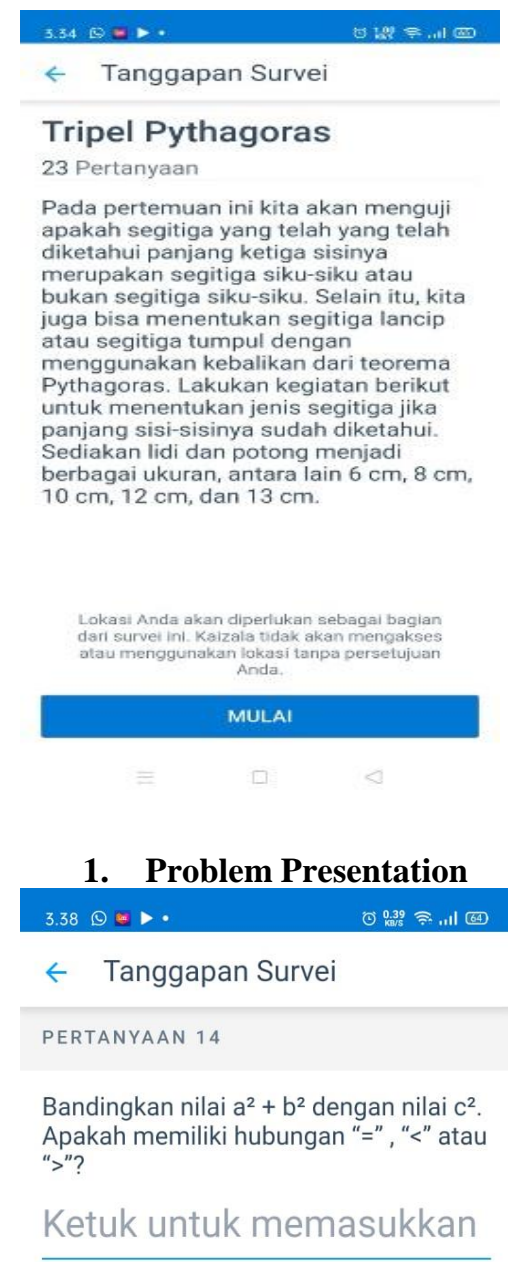

4. Data Analysis $3.38 \otimes \infty \sim$.

$\leftarrow$ Tanggapan Survei

PERTANYAAN 18

Gambarlah suatu segitiga dengan panjang ketiga sisinya berturut-turut 17 $\mathrm{cm}, 25 \mathrm{~cm}$, dan $38 \mathrm{~cm}$. Apakah segitiga yang dimaksud adalah segitiga sikusiku? Fotokan hasil pekerjaan kalian.

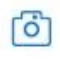

7. Proving the Hypothesis
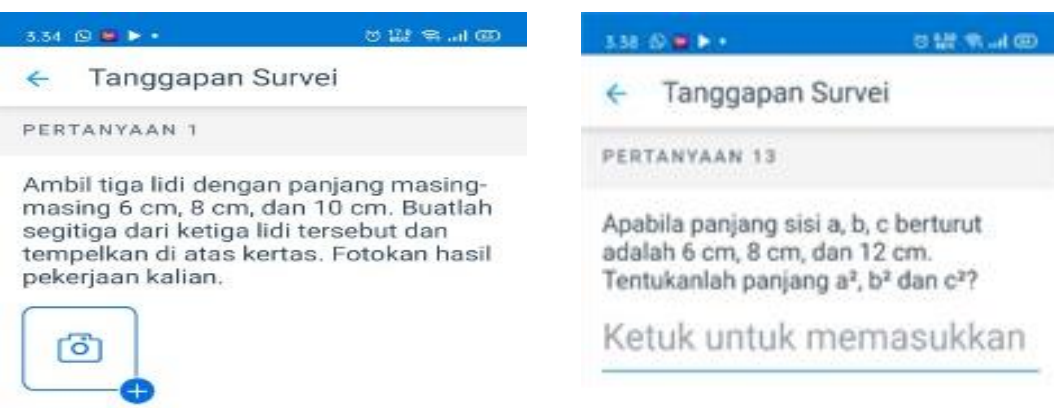

$\leftarrow$ Tanggapan Survei

PERTANYAAN 13

Apabila paniang sisi a, $b$, c berturut adalah $6 \mathrm{~cm}, 8 \mathrm{~cm}$, dan $12 \mathrm{~cm}$. Tentukanlah panjang $\mathrm{a}^{2}, \mathrm{~b}^{2}$ dan $\mathrm{c}^{2}$ ?

\section{Ketuk untuk memasukkan}

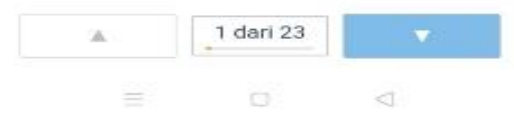

2. Trial and Error 3.38 (1)

$\leftarrow$ Tanggapan Survei

PERTANYAAN 15

Apa yang dapat kalian simpulkan dari jawaban pada pertanyaan 12 dan 14 ?

\section{Ketuk untuk memasukkan}

5. Creating a Hypothesis

\begin{tabular}{l}
$\leftarrow$ Tanggapan Survei \\
PERTANYAAN 21 \\
Manakah di antara kelompok tiga \\
bilangan berikut yang merupakan tripel \\
$\begin{array}{l}\text { Pythagoras? a. } \quad 10,12,14 \text { b. } \quad 7,13, \\
11 \quad 15\end{array}$ \\
Ketuk untuk memasukkan \\
\hline
\end{tabular}

\section{Exercises}

\section{Data Collection}

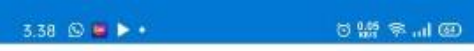

\section{$\leftarrow$ Tanggapan Survei}

PERTANYAAN 16

Buatlah kesimpulan tentang hubungan panjang ketiga sisi pada segitiga pertama, kedua dan ketiga?

\section{Ketuk untuk memasukkan}

\section{Conclusion}

Figure 3. Kaizala Teaching Materials Based on Exploration Stage

After the teaching materials were designed at the development stage, the researcher made a questionnaire validation of the teaching materials for expert assessment. Based on the validity test results of Kaizala teaching materials, the following calculation results are obtained:

Table 6. The Validity Test Results of Kaizala Teaching Materials

\begin{tabular}{lll}
\hline Component Aspect & Percentage & Category \\
\hline Content Fesibility & $87.36 \%$ & Valid \\
\hline Presentation Fesibility & $90.28 \%$ & Valid \\
\hline Language Fesibility & $87.11 \%$ & Valid \\
\hline Problem Solving Integration & $94 \%$ & Valid \\
\hline Average & $89.68 \%$ & Valid \\
\hline
\end{tabular}


From Table 6, it is known that the average value of the validity test results of Kaizala teaching materials is $89.68 \%$, with very valid criteria. These results indicate that Kaizala teaching materials that have been designed in this research can already be used. Besides each component, the teaching materials can be feasible in material content, presentation, language, and problem-solving integration. Although this teaching material is classified as very valid, the researcher also considers the inputs and suggestions for improvement provided by the experts. The research team took expert suggestions, and corrective steps are as follows:

Table 7. Suggestions and Corrective action

\begin{tabular}{cll}
\hline No & \multicolumn{1}{c}{ Suggestion } & \multicolumn{1}{c}{ Corrective action } \\
\hline 1 & $\begin{array}{l}\text { Add an image to the initial post of teaching } \\
\text { materials }\end{array}$ & $\begin{array}{l}\text { Adding pictures related to sub- } \\
\text { chapters of material in the initial } \\
\text { post of teaching materials }\end{array}$ \\
\hline 2 & Add contextual based problem solving & $\begin{array}{l}\text { Add contextual questions as practice } \\
\text { questions. }\end{array}$ \\
\hline 3 & $\begin{array}{l}\text { Fix question no } 4 \text { in the } 1^{\text {st }} \\
\text { the leaching material; } ;\end{array}$ & $\begin{array}{l}\text { Add elements that needed to be } \\
\text { known to the problem. }\end{array}$ \\
\hline 4 & $\begin{array}{l}\text { Permission to access student locations on } \\
\text { teaching materials should be disabled } \\
\text { because it makes it difficult for students with } \\
\text { poor internet connections to access teaching } \\
\text { materials }\end{array}$ & $\begin{array}{l}\text { Disabling student location access } \\
\text { before sharing teaching materials in } \\
\text { a group }\end{array}$ \\
\hline 5 & $\begin{array}{l}\text { Change the duration for accessing teaching } \\
\text { materials so that students can access teaching } \\
\text { materials for a long time }\end{array}$ & $\begin{array}{l}\text { Researchers changed the duration of } \\
\text { access to teaching materials from } \\
\text { only one week to two years. }\end{array}$ \\
\hline
\end{tabular}

The result of the improving teaching materials based on expert advice is called prototype 2 . At the implementation stage, the teaching materials which were prototype two, were tested on a limited basis to 17 students. The following is an example of student answers to the given teaching materials.

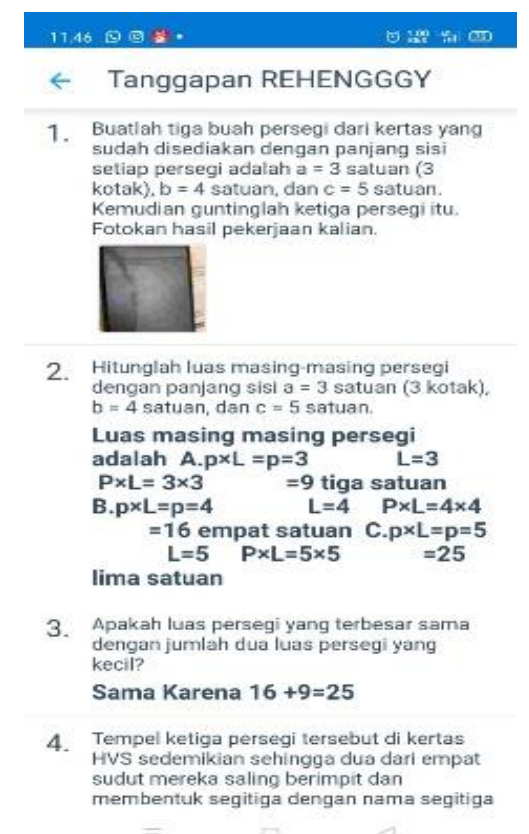

Figure 4. Examples of Student Answers on Kaizala Teaching Materials 
From the results of the limited trial, several errors were found that needed to be corrected, namely some typing errors, the picture in the question being asked did not exist, and the known elements in the question were still incomplete. Therefore, this readability test is carried out to minimize students' misunderstanding of the teaching materials provided.

In addition, reading with a good level of readability will increase interest in learning, memory, increase speed, reading efficiency, and maintain reading habits (Dewi \& Arini, 2018). Furthermore, to determine the practicality of teaching materials, students are given a questionnaire presented in the form of a statement that must be answered yes or no using a scoring according to the Guttman scale criteria. In this trial, the researchers found the lack of use of Kaizala teaching materials which were then revised or corrected for these deficiencies. The results of processing the questionnaire on the practicality of Kaizala teaching materials are presented as follows.

Table 8. The Results of the Kaizala Teaching Material Practicality Questionnaire

\begin{tabular}{llccc}
\hline No. & \multicolumn{1}{c}{ Questions } & Yes & No \\
\hline 1 & $\begin{array}{l}\text { Is the language used in the teaching materials } \\
\text { easy to understand? }\end{array}$ & $70.6 \%$ & $29.4 \%$ \\
\hline 2 & $\begin{array}{l}\text { Does this teaching material help you in } \\
\text { understanding the Pythagorean material? }\end{array}$ & $76.5 \%$ & $23.5 \%$ \\
\hline 3 & $\begin{array}{l}\text { Are you having trouble installing and using the } \\
\text { Kaizala application? }\end{array}$ & $88.2 \%$ & $11.8 \%$ \\
\hline 4 & $\begin{array}{l}\text { Do these teaching materials help you to carry } \\
\text { out exploration activities? }\end{array}$ & $82.4 \%$ & $17.6 \%$ \\
\hline 5 & $\begin{array}{l}\text { Does the design of this teaching material } \\
\text { motivate you to study Pythagorean material? }\end{array}$ & 76.5 & 23.5 \\
\hline 6 & $\begin{array}{l}\text { Is the quota needed to access teaching materials } \\
\text { huge? }\end{array}$ & 11.8 & 88.2 \\
\hline 7 & $\begin{array}{l}\text { Are you having trouble typing equations or } \\
\text { mathematical symbols in the Kaizala } \\
\text { application? }\end{array}$ & 34.7 & 35.3 \\
\hline 8 & $\begin{array}{l}\text { Are you interested in the display of this teaching } \\
\text { material? }\end{array}$ & 70.6 & 29.4 \\
\hline
\end{tabular}

The data analysis results on the practicality of teaching materials show that the average practicality score obtained is $77.2 \%$, and this is within the practical criteria. The lowest score in assessing the practicality of teaching materials is in question number 7 , which states that students have difficulty in typing equations or mathematical symbols in the Kaizala application. The research results of (Begg et al., 2021) also showed that students had difficulty in writing mathematical symbols in all STEM subjects. The improvement efforts made are by urging teachers to provide training on how to write numbers in the form of exponents and fractions in the Kaizala application. Writing symbols other than exponents and fractions can be circumvented by selecting the answer input in the form of images. Students must write down their answers on a worksheet, then take a photo of the answer.

In the language aspect, although $70.6 \%$ of students stated that the language used in the teaching materials was easy to understand. However, improvement efforts are still being made by rereading the teaching materials drafts to avoid ambiguous sentences or complicated sentences for students to understand. The improvement results are in the form of changes to the editorial sentences that are simple and easy to understand. In addition, the the questionnaire results also showed that there were $70.6 \%$ of students were interested in the 
display of Kaizala teaching materials. To increase students' interest in the display of teaching materials, the researcher added a picture at the beginning of the display of teaching materials. The improvement results based on the practicality questionnaire resulted in the Kaizala teaching material (prototype II) being developed.

In addition to the lack of teaching materials described previously, the advantages of teaching materials that are accessed on the Microsoft Kaizala application do not require a large quota. This statement certainly supports the implementation of problem-solving exploration activities using the Microsoft Kaizala application. 82.4\% of students stated that this teaching material helped them to carry out exploration activities. An exploratory approach can train students' mathematical problem-solving abilities (Sari, 2015; Susilawati et al., 2017). Another advantage of this Microsoft Kaizala application is that teaching materials can be edited by updating the content that has been created. This feature will help the teacher if there is an error in typing the question, so the teacher does not need to retype the teaching material from the beginning.

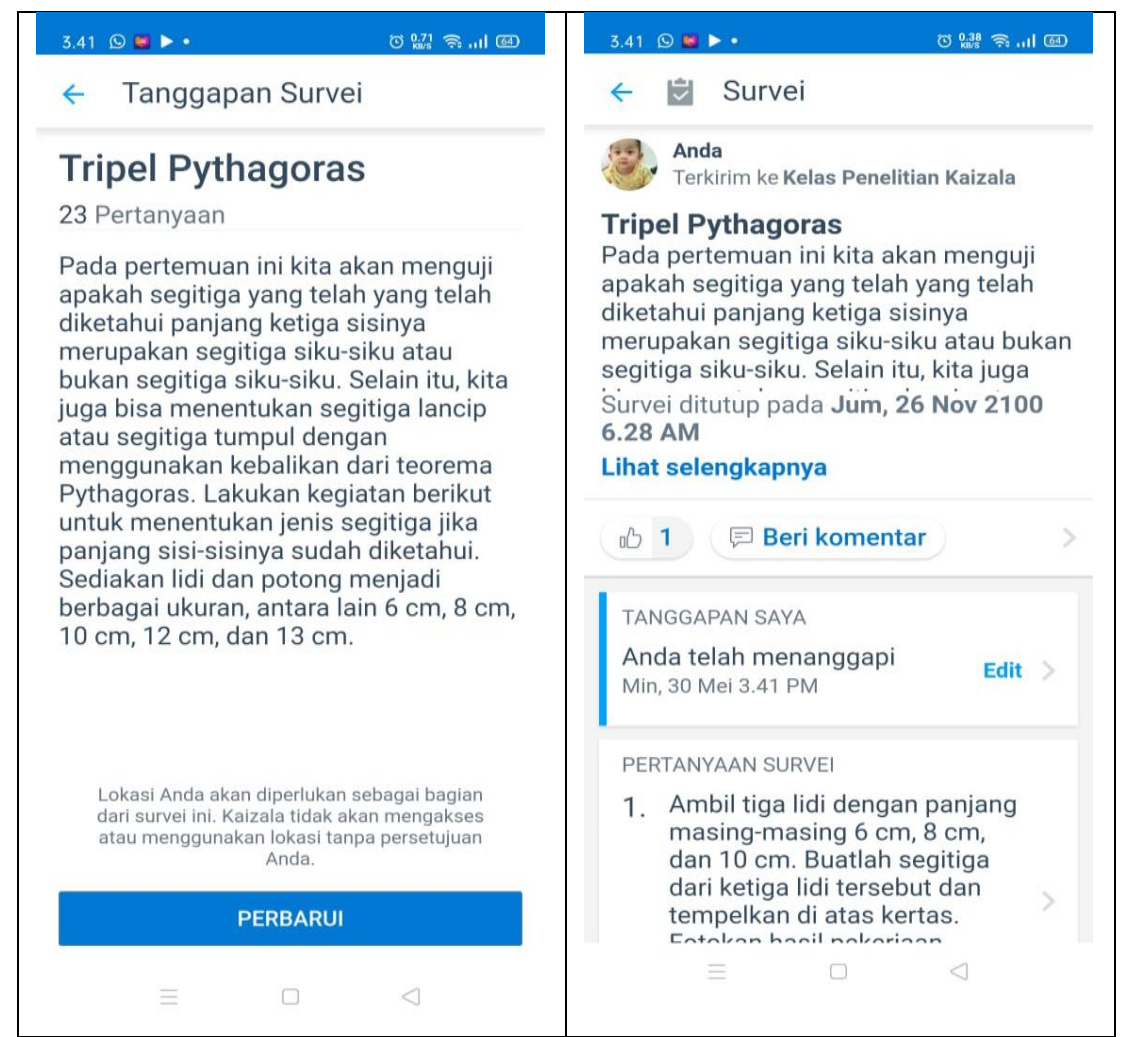

Figure 5. Kaizala Teaching Materials can be Updated and Students' Responses Edited

The Kaizala application also has the facility to view the group's history, even if new members just joined the group. This feature is an advantage of Kaizala that WhatsApp does not have. In the WhatsApp application, new members cannot see group posts before they are joined. The weakness of WhatsApp certainly makes it difficult for the teacher in the learning process because if a new member is added, the teacher must repost the file or the post they have made.

At the end of the provision of teaching materials, the teacher gives a problem-solving test to measure the effectiveness of the teaching materials produced. The results of the students' problem-solving ability tests are summarized in Table 9. 
Table 9. Analysis of the Effectiveness of Teaching Materials

\begin{tabular}{ccccccc}
\hline Test Type & $\begin{array}{c}\text { Lowest } \\
\text { Score }\end{array}$ & $\begin{array}{c}\text { Highest } \\
\text { Score }\end{array}$ & Average & $\begin{array}{c}\text { Standard Deviation } \\
\text { Difference }\end{array}$ & $d$ & Category \\
\hline Pretest & 0 & 20 & 5.94 & 37.54 & 1.98 & Large \\
\hline Postest & 72 & 100 & 80.4 & & 37 \\
\hline
\end{tabular}

To see the percentage of classical mastery learning, the researcher determined the minimum score for the students' classical learning mastery percentage, which was 75 . The analysis of students' problem-solving scores showed that $82 \%$ had exceeded the minimum score for learning mastery. These results are also strengthened by the effectiveness test results, which shows that using Kaizala teaching materials on problem-solving abilities is in the large category. These results are very encouraging, considering that so far, the effectiveness of using social media in improving problem-solving abilities is still relatively low (Saragih \& Ansi, 2020; Yulianto, 2020; Zakiyah et al., 2021). It means that the teaching materials produced in this research have met the effective criteria. In other words, Kaizala teaching materials are effective in facilitating students' problem-solving exploration activities. Based on several previous test results, it can be concluded that the final product (final prototype) of Kaizala teaching materials is feasible to use because it meets three criteria, namely valid, practical, and effective.

\section{CONCLUSIONS}

Based on the data analysis results and discussion described, several conclusions can be drawn. First, the produced teaching materials are Kaizala teaching materials based on problemsolving exploration. The Kaizala teaching material in question contains stages of exploration such as presenting problems, trial and error, data analysis, data or information collection, making hypotheses, inferences, hypothesis proofing, and practice questions. Second, the validation results show that the developed teaching materials are valid in content material, language, presentation, and problem-solving integration. Third, the results of the practicality assessment by students indicate that the developed teaching materials are practical. Fourth, the developed Kaizala teaching materials were also effective. In contrast, as many as $82 \%$ of the test subjects obtained a score of not less than 75, and the effect size value belongs to the large category. Based on these conclusions, the researcher suggests that the Microsoft Kaizala application can design teaching materials that support exploratory problem-solving activities.

For further research, the researcher suggests developing a social media platform with survey features, such as Microsoft Kaizala. However, the application can be accessed via a website link without installing it on the student's device. The goal is not to burden students' cell phone memory. The platform is also expected to support the writing of mathematical symbols and allow students to create two- or three-dimensional graphics. In addition, there is a break room feature for limited group discussions that the teacher and group members can only see. So, in addition to support problem-solving exploration activities, this platform can also support cooperative learning activities.

\section{AUTHOR CONTRIBUTIONS STATEMENT}

MNS and AS worked as the main drafter in this research. Data collection and instrument design assisted by IR and HSM. 


\section{REFERENCES}

Abdiyani, S., Khabibah, S., \& Rahmawati, N. D. (2019). Profil kemampuan pemecahan masalah matematika siswa SMP berdasarkan langkah-langkah polya ditinjau dari adversity quotient. Al-Khwarizmi: Jurnal Pendidikan Matematika Dan Ilmu Pengetahuan Alam, 7(2), 123-134.

Abuhammad, S. (2020). Barriers to distance learning during the COVID-19 outbreak: A qualitative review from parents ' perspective. Heliyon, 6(11), 1-5.

Akbar, S. (2017). Instrumen perangkat pembelajaran cetakan kelima. Bandung: PT Remaja Rosdakarya.

Aminullah, A., Ikram, I., Chandra, F., Fitriani, N., Wasna, W., Misna, M., \& Elihami, E. (2021). Proses pembelajaran selama masa pandemi COVID-19 (studi pelaksanaan PLP dasar). Maspul Journal of Community Empowerment, 3(1), 21-26.

Anugrahana, A. (2020). Hambatan, solusi dan harapan: Pembelajaran daring selama masa pandemi COVID-19 oleh guru sekolah dasar. Scholaria: Jurnal Pendidikan Dan Kebudayaan, 10(3), 282-289.

Ansori, M. (2019). Integrating HOTS into EFL classroom: Teacher's perception and classroom behavior. The 16th Jeta International Conference, July, 13-19.

Apriadi, M. A., Elindra, R., \& Harahap, M. S. (2021). Analisis kemampuan pemecahan masalah matematis siswa sebelum dan sesudah masa pandemi COVID-19. Jurnal MathEdu (Mathematic Education Journal), 4(1), 133-144.

Argaheni, N. B. (2020). A systematic review: The impact of online lectures during the COVID-19 pandemic against indonesian students. Placentum Jurnal Ilmiah Kesehatan Dan Aplikasinya, 8(2), 99-108.

Asmuni. (2020). Problematika pembelajaran daring di masa pandemi COVID-19 dan solusi pemecahannya. Jurnal Paedagogy: Jurnal Penelitian dan Pengembangan Pendidikan, 7(4), 281-288.

Barham, A. I. (2019). Investigating the development of pre-service teachers' problem-solving strategies via problem-solving mathematics classes. European Journal of Educational Research, 9(1), 129-141.

Becker, L. A. (2000). Effect size ( ES ).

Begg, M., Pierce, R. (2021). Symbols : The challenge of subscripts. International Journal of Mathematical Education in Science and Technology, 52(5), 1-8.

Branca, N. A. (1980). Problem solving as a goal, process, and basic skill. Reston, VA: NCTM

Dewi, N. R., \& Arini, F. Y. (2018). Uji keterbacaan pada pengembangan buku ajar kalkulus berbantuan geogebra untuk meningkatkan kemampuan pemecahan masalah dan representasi matematis. Prisma, Prosiding Seminar Nasional Matematika, 1, 299-303.

Dharmayana, I. W., Kumara, A., \& Wirawan, Y. G. (2012). Keterlibatan siswa (student engagement) sebagai mediator kompetensi emosi dan prestasi akademik. Jurnal Psikologi, 39(1), 76-94.

Felmer, P., Liljedahl, P., \& Koichu, B. (2019). Problem solving in mathematics instruction and teacher professional development. Springer International Publishing.

Gracin, D. G. (2018). Requirements in mathematics textbooks : A five- dimensional analysis of textbook exercises and examples. International Journal of Mathematical Education in Science and Technology, 49(7), 1003-1024. 
Gunawan, G., Suranti, N. M. Y., \& Fathoroni, F. (2020). Variations of models and learning platforms for prospective teachers during the COVID-19 pandemic period. Indonesian Journal of Teacher Education, 1(2), 61-70.

Huzaimah, P. Z., \& Amelia, R. (2021). Hambatan yang dialami siswa dalam pembelajaran daring matematika pada masa pandemi COVID-19. Jurnal Cendekia: Jurnal Pendidikan Matematika, 05(1), 533-541.

Jäder, J., Lithner, J., \& Sidenvall, J. (2020). Mathematical problem solving in textbooks from twelve countries. International Journal of Mathematical Education in Science and Technology, 51(7), 1120-1136.

Jusnita, E. (2018). Pengaruh kecerdasan emosional dan penguasaan konsep IPA terhadap kemampuan pemecahan masalah IPA (survey pada siswa kelas VIII MTs se KKM 23 Jakarta Selatan). Alfarisi: Jurnal Pendidikan MIPA, 1(2), 181-187.

Kemdikbud. (2020). Panduan penyelenggaraan pembelajaran pada tahun ajaran 2020/2021 dan tahun akademik 2020/2021 di masa pandemi coronavirus disease 2019 (COVID19). Jakarta: Kementerian Pendidikan Dan Kebudayaan.

Kurniawan, R. I., Nindiasari, H., \& Setiani, Y. (2020). Analisis kemampuan pemecahan masalah matematis dengan menggunakan pembelajaran daring. Jurnal Inovasi dan Riset Pendidikan Matematika, 1(2), 150-160.

Microsoft. (2020). Mengenal Kaizala.

Muruganantham, G. (2015). Developing of e-content pcakge by using ADDIE model. International Journal of Applied Research, 1(3), 52-54.

Nieveen, N., Gustafson, K., Branch, R. M., \& Van Den Akker, J. (1999). Design approaches and tools in education and training. London: Kluwer Academic Publisher.

Octaberlina, L. R., \& Muslimin, A. I. (2020). EFL students perspective towards online learning barriers and alternatives using moodle/google classroom during COVID-19 pandemic. International Journal of Higher Education, 9(6), 1-9.

Pellegrino, J. W. (2017). Teaching, learning and assessing 21st century skills. OECD.

Pogaga, K. P. N. (2020). Variasi dalam pembelajaran sebagai upaya menstimulus keterlibatan siswa dalam pembelajaran daring kelas X. Disertasi Universitas Pelita Harapan.

Polya, G. (2004). How to solve it: A new aspect of mathematical method. Princeton University Press.

Reyes, C. R., Brackett, M. A., \& Rivers, S. E. (2012). Classroom emotional climate, student engagement, and academic achievement. Journal of Educational Psychology, 104(3), 113.

Rianti, R. (2018). Profil kemampuan pemecahan masalah matematis siswa SMP pada materi bangun ruang sisi datar. Jurnal Pendidikan Tambusai, 2(2), 802-812.

Saefulmilah, R. M. I., \& Saway, M. H. M. (2020). Hambatan-hambatan pada pelaksanaan pembelajaran daring di SMA riyadhul jannah jalan cagak subang. Nusantara: Jurnal Pendidikan dan Ilmu Sosial, 2(3), 393-404.

Saepudin, C. (2019). Analisis literasi TIK guru SMK di kabupaten Bandung berdasarkan demografi. Jurnal Teknik Informatika, 11(3), 1-7.

Saragih, E. M., \& Ansi, R. Y. (2020). Efektivitas penggunaan whatsapp group selama pandemi COVID-19 bagi pelaku pendidik. Seminar Nasional Multidisiplin Ilmu Universitas Asahan Ke-4, September, 207-212. 
Saragih, S., \& Habeahan, W. L. (2017). The improving of problem solving ability and students' creativity mathematical by using problem based learning in SMP negeri 2 Siantar. Journal of Education and Practice, 5(35), 123-132.

Sari, N. . (2015). Peningkatan kemampuan pemecahan masalah matematis dengan metode eksplorasi. AlphaMath: Journal of Mathematics Education, 1(1).

Sari, N. M., Yaniawati, P., Darhim, \& Kartasasmita, B. G. (2019). The effect of different ways in presenting teaching materials on students' mathematical problem solving abilities. International Journal of Instruction, 12(4), 495-512. https://doi.org/10.29333/iji.2019.12432a

Septiani, E., \& Setyowati, L. (2020). Penggunaan media pembelajaran secara daring terhadap pemahaman belajar mahasiswa. Seminar Nasional Pascasarjana Universitas Negeri Jakarta, 121-128.

Silaban, B. (2014). Hubungan antara penguasaan konsep fisika dan kreativitas dengan kemampuan memecahkan masalah pada materi pokok listrik statis. Jurnal Penelitian Bidang Pendidikan, 20(1), 65-75.

Son, J.-W., \& Lee, M. Y. (2020). Exploring the relationship between preservice teachers' conceptions of problem solving and their problem-solving performances. International Journal of Science and Mathematics Education, 19, 1-22.

Susilawati, E., Syaf, A. H., \& Susilawati, W. (2017). Pendekatan eksplorasi berbasis intuisi pada kemampuan pemecahan masalah matematis. Jurnal Analisa, 3(2), 138-147.

Susilawati, N. P. . (2020). Pengembangan bahan ajar barisan dan deret berbasis mobile learning berbantuan microsoft kaizala berorientasi kemampuan berpikir kreatif dan self efficacy siswa. Tesis Pascasarjana Universitas Pasundan.

Yulianto, D. Y. (2020). Pengaruh pembelajaran daring pengguna platform digital terhadap pemecahan masalah matematis dan sikap kritis siswa di MA Daar El Qolam. Symmetry: Pasundan Journal Of Research In Mathematics Learning And Education, 5(1), 107128.

Zakiyah, S., Usman, K., \& Gobel, A. P. (2021). Deskripsi kemampuan pemecahan masalah matematika melalui pembelajaran daring pada materi persamaan kuadrat. Jambura Journal of Mathematics Education, 2(1), 28-35. 